\title{
Ефективність препарату Мастодинон ${ }^{\circledR}$ для корекції масталгії у жінок у пре- і перименопаузі
}

Н.І. Рожкова', , І.І. Бурдіна', С.Б. Запірова ${ }^{1}$, М.Л. Мазо ${ }^{1}$, С.П. Прокопенко ${ }^{1}$ О.Е. Якобс

${ }_{1}^{1}$ ФДБУ Московський науково-дослідний онкологічний інститут ім. П.О. Герцена, ФДБУ Національний медичний дослідний радіологічний центр МОЗ Росії, 125284, Росія, Москва, 2-й Боткінський проїзд, б. 3

гФДАОЗ ВО Російський університет дружби народів, 117198, Росія, Москва, вул. Міклухо-Маклая, б. 6

Рожкова Н.І., Бурдіна І.І., Запірова С.Б. та ін. Ефективність препарату Мастодинон® для корекції масталгії в жінок у пре- і перименопаузі. Гінекологія. 2016; 18 (6): 28-31. (Переклад з російської)

\begin{abstract}
Мета дослідження - вивчення ефективності застосування препарату Мастодинон ${ }^{\circledR}$ для лікування масталгії в жінок у пре- і перименопаузі. Матеріали та методи. Дослідження проводилося протягом 12 міс. Пацієнтки, що скаржилися на біль у молочній залозі, проходили комплексне обстеження (клініко-рентгеносонографічне), анкетування під час першого візиту й надалі кожні 6 міс. Прийом і обстеження пацієнток проводилися тричі: до початку лікування, через 6 місяців після його початку й через рік. Терапія проводилася лікарським препаратом рослинного походження Мастодинон ${ }^{\circledR} 2$ курсами по 3 міс із перервами 2,5-3 міс.

Результати. Нами було обстежено 38 пацієнток віком 45-56 років. Більшість жінок цієї групи протягом багатьох років спостерігалися з приводу мастопатії різних форм і ступенів вираженості. Через 6 міс після початку вживання Мастодинону більшість пацієнток відзначали зменшення або відсутність болю у молочній залозі, поліпшення психоемоційного стану. Позитивний ефект різного ступеня спостерігався у $71,05 \%$ пацієнток.

Через 1 рік після початку лікування виявлено стабілізацію лікувальної дії препарату Мастодинон ${ }^{\circledR}$ у $83,3 \%$ випадків у вигляді відсутності відновлення болю у молочній залозі або відсутності посилення больового симптому у тих жінок, у яких біль не був повністю купірований. Мастодинон ${ }^{\circledR}$ показав високу ефективність, добру переносимість при лікуванні мастопатії у жінок у пре- і перименопаузі, підвищив рівень якості життя пацієнток.
\end{abstract}

Ключові слова: мастопатія, масталгія, Мастодинон ${ }^{\circledR}$

\section{Efficacy of Mastodinone ${ }^{\circledR}$ for mastalgia correction in pre- and perimenopausal women N.I. Rozhkova, I.I. Burdina, S.B. Zapirova, M.L. Mazo, S.P. Prokopenko, O.E. Yakobs}

The purpose of the study wasto examine the effectiveness of the drug Mastodynon ${ }^{\circledR}$ for the treatment of mastopathy in pre- and perimenopausal women. Materials and methods. The research was carried out within 12 months. Patient presenting complaints of pain in the breast, passed a comprehensive examination (clinical and X-ray and/or sonographic) and questionnaires at the first visit and every 6 months. The plant-based drug Mastodynon ${ }^{\circledR}$. Results. We examined 38 patients aged 45-56 years. Most women in this group for many years were observed due to mastopathy of different forms and degrees of severity. After 6 months after start of treatment with Mastodynon ${ }^{\circledR}$ the majority of patients reported decrease or absence of pain in the breasts, improvement of psycho-emotional condition. The positive effect of various degree was observed in $71,05 \%$ of the patients.

After 1 year revealed a stabilization of the therapeutic effect of the drug Mastodynon ${ }^{\circledR}$ in $83,3 \%$ of cases. Mastodynon ${ }^{\circledR}$ has shown high effectiveness, good tolerability in the treatment of mastopathy in women of pre- and perimenopausal age, it has improved thepatients quality of life. Keyzords: mastopathy, mastalgia, Mastodynon ${ }^{\circledast}$.

\section{Эффективность препарата Мастодинон ${ }^{\circledR}$ для коррекции масталгии у женщин в пре- и перименопаузе Н.И. Рожкова, И.И. Бурдина, С.Б. Запирова, М.Л. Мазо, С.П. Прокопенко, О.Э. Якобс}

Цель исследования - изучение эффективности применения препарата Мастодинон® для лечения масталгии у женщин в пре- и перименопаузе. Материаль и методы. Исследование проводилось в течение 12 мес. Пациентки, предъявляющие жалобы на боли в молочной железе, проходили комплексное обследование (клинико-рентгеносонографическое) и анкетирование при первом визите и далее каждые 6 мес. Прием и обследование пациенток проводились трижды: до начала лечения, через 6 мес после его начала и через год. Терапия проводилась лекарственным препаратом растительного происхождения Мастодинон ${ }^{\circledR} 2$ курсами по 3 мес с перерывами 2,5-3 мес.

Peзультаты. Нами было обследовано 38 пациенток в возрасте 45-56 лет. Большинство женщин данной группы многие годы наблюдались по поводу мастопатии различных форм и степеней выраженности. Через 6 мес после начала приема Мастодинона большинство пациенток отметили уменьшение или отсутствие болезненности в молочной железе, улучшение психоэмоционального состояния. Положительный эффект разной степени наблюдался у 71,05\% пациенток. Через 1 год после начала лечения выявлена стабилизация лечебного действия препарата Мастодинон ${ }^{\circledR}$ в 83,3\% случаев в виде отсутствия возобновления болей в молочной железе или отсутствия усиления болевого симптома у тех женщин, у которых боли не были полностью купированы. Мастодинон® показал высокую эффективность, хорошую переносимость при лечении мастопатии у женщин в пре- и перименопаузе, повысил уровень качества жизни пациенток. Ключевые слова: мастопатия, масталгия, Мастодинон ${ }^{\circledR}$.

$\prod_{\text {оброякісні зміни молочної залози належать до найпоши- }}$ реніших захворювань у жінок. Вони різні за клінічними,
морфологічними й етіологічним ознаками. Важливою відмін-
ною рисою цих процесів є складність чіткого диференціюван-
ня фізіологічних і патологічних змін. Це зумовлено тим, що
навіть нормальна будова молочної залози характеризується
значною варіабельністю не тільки у різних жінок, але й в тієї
самої жінки залежно від стану репродуктивної системи, пері-
оду менструального циклу, віку [1-5].
Досягнення науки, сучасні умови життя створюють основу для збільшення чисельності й віку населення, зокрема й жіночого. На сьогодні жінки у постменопаузі становлять приблизно $10 \%$ від загального населення планети. Щорічно до цього числа додається 25 млн, а до 2020 р. очікується збільшення цієї цифри до 47 млн. Є прогноз, що до 2030 року кількість жінок віком понад 30 років становитиме 1,2 млрд [6-8]. У зв'язку з цим у сучасному суспільстві зростає інтерес до проблем здоров'я жінок старшої вікової групи. Значну увагу мамологи приділяють ліку- 


\section{Г І Н Е КО ЛОГ І Я}

ванню дифузних доброякісних захворювань у жінок дітородного віку, часом забуваючи і зменшуючи акцент на проблемах пацієнток у пре- і менопаузальний період.

Тривалість життя зростає, і питання його якості набуває першочергового значення $[3,9,10]$. На будь-якому відрізку життя важливий оптимальний комфорт фізичного й емоційного стану. Одним із найчастіших симптомів, які супроводжують багатьох жінок протягом довгих років, є масталгія. За даними літератури, у перименопаузі на неї страждають не менше $10 \%$ жінок [7, 11]. Якщо у дітородний період біль у молочній залозі характеризується певною циклічністю, що залежить від менструального циклу, то у більш пізньому віці масталгія стає більш непередбачуваною у часовому відношенні.

Приблизно у 50-60\% пацієнток масталгія зникає після настання менопаузи. Але багато жінок продовжують відчувати дискомфорт (больові відчуття, почуття розпирання, набряклості тощо) протягом багатьох років. Вазомоторні симптоми, порушення сну, психоемоційні порушення й масталгія тягнуть за собою зниження якості життя. Ці прояви клімактеричного синдрому потребують уваги й лікування, яке повинно враховувати всі особливості гормонального статусу й супутні проблеми [2-5, 9].

Призначення терапії має базуватися на чітко встановленому діагнозі, беручи до уваги широкий спектр клінічних проявів, даних анамнезу, ендокринного, неврологічного, гінекологічного стану, гормонального фону.

Протягом багатьох років спостерігається тенденція призначення замісної гормональної терапії у пре- і перименопаузі без чітких показань «для поліпшення самопочуття», зокрема й для поліпшення стану молочної залози. Останні 10-15 років число протипоказань для застосування гормональної терапії значно зменшилося, а колишні абсолютні протипоказання стали відносними $[1,6,11]$. Такий підхід до призначення гормональних препаратів є сумнівним. У сучасних умовах збільшення кількості доброякісної і злоякісної патології молочної залози й репродуктивних органів гормональна терапія повинна призначатися суворо за показаннями з урахуванням бажання пацієнтки.

Для лікування проявів масталгії у пре- і перименопаузі ми використовували препарат Мастодинон ${ }^{\circledR}$. Препарат безпосередньо, а також через регуляцію стероїдогенезу у яєчниках впливає на молочну залозу. Цей вплив досягається наявністю у препараті основного діючого компонента Вітекса священного (Vitex agnus-castus - VAC). Мастодинон ${ }^{\circledR}$ діє на клітини-лактотрофи передньої долі гіпофіза, пригнічуючи надмірну секрецію пролактину (спонтанну або індуковану). Шляхом усунення дисба-

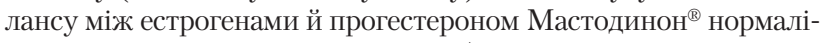
зує стан молочної залози й купірує больовий синдром.

Позитивний вплив, який справляє Мастодинон ${ }^{\circledR}$, зумовлений широким спектром його біологічної активності. Проведеними раніше дослідженнями встановлено, що виділені з рослини Vitex agnus-castus біциклічні дитерпени, які зв'язують опіоїдні рецептори і $\beta$-ендорфіни, мають допамінергічну, пролактинінгібуючу, холінергічну, слабку естрогенну активність. Плоди рос- лини містять іридоїди, флавоноїди та інші біологічно активні компоненти, що діють так само, як гормон жовтого тіла [12].

Головним механізмом дії Мастодинону є стимулювальний вплив біологічно активних речовин, які він містить, дитерпенів на дофамінові $\mathrm{D}_{2}$-рецептори передньої долі гіпофіза, що приводить до скорочення продукції аденозинмонофосфату й підвищення вироблення допаміну, який інгібує секрецію пролактину. На цьому тлі відбувається регрес патологічних процесів у молочних залозах, купірування мастодинії при мастопатії і передменструальному синдромі [13-16].

Вивчено активність Мастодинону щодо збільшення коефіцієнта співвідношення метаболітів естрогенів (2-OHE $1 / 16 \alpha$ $\left.\mathrm{OHE}_{1}\right)$, що є біомаркером вираженості проліферації в естрогенчутливих органах і тканинах, експресії цитокінів, що відображають стан спонтанних апоптотичних реакцій. VAC підвищуе продукцію лімфоцитами інтерлейкіну-10, який чинить антипроліферативну дію за рахунок активації апоптозу, а також знижує продукцію фактора некрозу пухлин, що стимулює проліферативні процеси [17].

Ми спостерігали за групою жінок із 38 пацієнток у віковій групі від 45 до 56 років. Середній вік пацієнток становив 49 50 років. У 22 жінок спостерігався регулярний менструальний цикл, в 11 - протягом року нерегулярний, у 5 - останні 3-4 міс менструації були відсутні.

Більшість жінок цієї групи протягом багатьох років спостерігалися з приводу мастопатії різних форм і ступенів вираженості. Усі пацієнтки скаржилися на біль, відчуття розпирання й набухання молочних залоз, перепади настрою. Пацієнтки відзначали безсоння, періодичні відчуття тяжкості й набряклості у молочних залозах.

3 метою оцінювання ефективності лікарського препарату всі пацієнтки пройшли комплексне обстеження. Були проведені клінічне, мамографічне й сонографічне дослідження. У всіх 38 пацієнток була виключена злоякісна патологія молочної залози.

У групу, що досліджувалася, не входили пацієнтки, які страждали на тяжкі хронічні захворювання, жінки, які використовували гормональне, знеболювальне лікування, інші фітопрепарати й вітамінотерапію.

Спостереження проводилося протягом 1 року.

Перед призначенням терапії пацієнткам пропонувалося заповнити анкету, у якій були питання про наявність скарг щодо стану молочної залози (масталгії, набряклості, різні неприємні відчуття), про вазомоторні та психоемоційні прояви (зміна настрою, нервозність, плаксивість, зміни апетиту тощо).

Пацієнтки вели щоденники протягом усього курсу застосування препарату Мастодинон ${ }^{\circledR}$, у яких відзначали певні зміни стану й самопочуття.

Мастодинон $^{\circledR}$ призначався курсами по 1 таблетці 2 рази на день протягом 3 міс, з перервами 2,5-3 міс. Отже, було проведено два повних курси вживання препарату.

Контрольне динамічне обстеження проводилося через 6 міс, воно включало клінічний огляд і сонографію молочної залози.

Ефективність застосування препарату Мастодинон ${ }^{\circledR}$

\begin{tabular}{|c|c|c|c|}
\hline \multirow{2}{*}{ Скарги до початку прийому Мастодинону } & \multicolumn{3}{|c|}{ Кількість пацієнток, у яких спостерігалися скарги } \\
\cline { 2 - 4 } & До лікування & Після 1-го курсу лікування & Після 2-го курсу лікування \\
\hline Біль у молочній залозі різного ступеня & 38 & 9 & 2 \\
\hline Перепади настрою & 11 & 2 & 0 \\
\hline Безсоння, порушення сну & 12 & 4 & 0 \\
\hline Загальна набряклість & 9 & 0 & 2 \\
\hline Дратівливість, втома & 16 & 5 & 0 \\
\hline Депресія, зневіра & 1 & 0 & 0 \\
\hline
\end{tabular}




\section{Г І Н Е КО ЛОГ І Я}

Заключне дослідження через 1 рік після початку лікування включало клінічне, рентгенологічне й сонографічне обстеження з метою оцінювання динаміки процесу за об'єктивними критеріями.

При кожному відвідуванні лікаря пацієнтки робили позначки за візуальною аналоговою шкалою, визначаючи ступінь вираженості больових відчуттів між двома крайніми точками (від «болю немає» до «найсильніший біль»). Використовувалася й шкала гримас болю (від 0 до 10), яка візуально відображала емоційний стан залежно від наявності або відсутності больового синдрому (масталгії).

На початку дослідження під час заповнення щоденника самопочуття пацієнтки відзначали:

- наявність схильності до набряклості обличчя, верхніх і нижніх кінцівок - 9 (21,3\%);

- перепади настрою - 11 (28,9\%);

- депресія, зневіра - 1 (2,6\%);

- дратівливість, нервозність, втома - 16 (42,1\%);

- безсоння, порушення сну - 12 (31,5\%);

- болючість молочних залоз, відчуття тяжкості й набряклості тканин молочних залоз - 38 (100\%).

Аналіз щоденників, які пацієнтки заповнювали кожного дня, виявив, що перші відгуки на проведене лікування препаратом Мастодинон ${ }^{\circledR}$ починали з'являтися на 15-21-у добу терапії. Дві пацієнтки відзначили поліпшення самопочуття на 7-10-у добу.

На момент повторного вживання, через 6 міс, позитивний ефект тією чи іншою мірою спостерігався у 27 (71,05\%) пацієнток. В 1 (2,6\%) випадку було відзначено посилення масталгії, в 1 (2,6\%) випадку спостерігалася алергійна реакція (алергійний риніт), 9 (23,6\%) пацієнток не спостерігали зміни самопочуття. Із загальної кількості у 2 (5,26\%) випадках відзначалося збільшення маси тіла на 3-4 кг. Але необхідно зазначити, що це не зупинило жінок, і вони продовжували вживання препарату, оскільки відчули виражене поліпшення самопочуття, що значно покращило психоемоційний настрій. Збільшення маси тіла не мало чіткого зв'язку із застосуванням препарату Мастодинон ${ }^{\circledR}$.

Контрольне клініко-сонографічне обстеження через 6 міс не виявило помітних візуальних змін стану молочних залоз у всіх пацієнток.
Через 6 міс вживання препарату Мастодинон ${ }^{\circledR}$ пацієнтки оцінювали переносимість лікування: погана - 2 (5,2\%), задовільна - 14 (36,8\%), хороша - 17 (44,7\%), відмінна - 5 (13,1\%). Погана переносимість проявилася у 2 пацієнток. В однієї з них була зареєстрована алергійна реакція, в іншої - масталгія, що тривала, і причиною якої була неврологічна патологія (міозит).

Більшість пацієнток відзначали зменшення або відсутність хворобливості/набряклості молочної залози, поліпшення настрою і сну, зменшення дратівливості, поліпшення загального самопочуття (таблиця).

Дві пацієнтки відмовилися продовжувати вживання препарату через наявність неврологічної патології (міозит) і алергійної реакції.

Динамічне комплексне клініко-рентгеносонографічне обстеження 36 пацієнток через 12 міс засвідчило незначне поліпшення стану молочних залоз у формі зниження щільності, набряклості структурних елементів. В окремих випадках спостерігалося зменшення кількості кіст і їхніх розмірів. Стабілізація позитивного ефекту у формі зменшення у 17 (47,2\%) або відсутності у 13 (36,1\%) хворобливих відчуттів спостерігалася у 30 (83,3\%) пацієнток; 6 (16,6\%) пацієнток відзначили незначне поліпшення самопочуття, але масталгія, як і раніше, їх турбувала. Цій групі були надані рекомендації щодо відвідування невропатолога для виключення патології хребта. П'ятнадцять пацієнток відзначили явний позитивний ефект, виявили бажання пролонгувати застосування препарату Мастодинон ${ }^{\circledR}$.

\section{ВИСНОВКИ}

1. Препарат Мастодинон ${ }^{\circledR}$ продемонстрував свою високу ефективність і хорошу переносимість під час лікуванні мастопатії у жінок у пре- і перименопаузі. Більше 80\% пацієнток відзначили позитивний ефект застосування Мастодинону.

2. Призначення препарату Мастодинон ${ }^{\circledR}$ дало змогу добитися поліпшення психологічного й емоційного стану, що, безсумнівно, підвищило рівень якості життя пацієнток.

3. Отримані протягом 12 міс результати дослідження дають змогу зробити висновок про необхідність тривалого застосування препарату Мастодинон ${ }^{\circledR}$ для отримання більш вираженого ефекту лікування.

\section{Відомості про авторів}

Рожкова Надія Іванівна - Національний центр онкології репродуктивних органів ФДБУ МНДОІ ім. П.О. Герцена, ФПК РУДН, президент Російської асоціації мамологів, член Свропейської асоціації радіологів. E-mail: Rozhkova@rncrr.ru

Бурдіна Ірина Ігорівна - ЦНРО ФДБУ МНДОІ ім. П.О. Герцена

Запірова Саміра Бадрузаманівна - ЦНРО ФДБУ МНДОІ ім. П.О. Герцена

Мазо Михайло Львович - ЦНРО ФДБУ МНДОІ ім. П.О. Герцена

Прокопенко Сергій Павлович - ЦНРО ФДБУ МНДОІ ім. П.О. Герцена

Якобс Ольга Едмундівна - ЦНРО ФДБУ МНДОІ ім. П.О. Герцена

\section{Information about the author}

Rozhkova Nadiia I. - P.A.Herzen Moscow Research Institute of Oncology of National Medical Research Radiological Centre of the Ministry of Health of the Russian Federation. FPD PFUR, President of the Russian Association of Mammologists, Member of the European Association of Radiologists, 125284, Russian Federation, Moscow, 2-i Botkinskii proezd, d. 3. E-mail: Rozhkova@rncrr.ru

Burdina Iryna I. - P.A.Herzen Moscow Research Institute of Oncology of National Medical Research Radiological Centre of the Ministry of Health of the Russian Federation

Zapirova1 Samira B. - P.A.Herzen Moscow Research Institute of Oncology of National Medical Research Radiological Centre of the Ministry of Health of the Russian Federation

Mazo Mykhailo L. - P.A.Herzen Moscow Research Institute of Oncology of National Medical Research Radiological Centre of the Ministry of Health of the Russian Federation

Prokopenko Serhii P. - P.A.Herzen Moscow Research Institute of Oncology of National Medical Research Radiological Centre of the Ministry of Health of the Russian Federation

Yakobs Olga E. - P.A.Herzen Moscow Research Institute of Oncology of National Medical Research Radiological Centre of the Ministry of Health of the Russian Federation 


\section{Г І НЕКО ЛОГІ Я}

\section{Сведения об авторах}

Рожкова Надежда Ивановна - Национальный центр онкологии репродуктивных органов ФГБУ МНИОИ им. П.А. Герцена, ФПК РУДН, президент Российской ассоциации маммологов, член Европейской ассоциации радиологов. E-mail: Rozhkova@rncrr.ru

Бурдина Ирина Игоревна - ЦНРО ФДБУ МНИОИ им. П.А. Герцена

Запирова Самира Бадрузамановна - ЦНРО ФДБУ МНИОИ им. П.А. Герцена

Мазо Михаил Львович - ЦНРО ФДБУ МНИОИ им. П.А. Герцена

Прокопенко Сергей Павлович - ЦНРО ФДБУ МНИОИ им. П.А. Герцена

Якобс Ольга Эдмундовна - ЦНРО ФДБУ МНИОИ им. П.А. Герцена

\section{СПИСОК ЛІТЕРАТУРИ}

1. Бурдина Л.М. Клинико-рентгенологические особенности заболеваний молочных желез у гинекологических больных репродуктивного возраста с нейроэндокринной патологией. Автореф. дис. ... д-ра мед. наук. M., 1993. / Burdina L.M. Kliniko-rentgenologicheskie osobennosti zabolevanii molochnykh zhelez u ginekologicheskikh bol'nykh reproduktivnogo vozrasta s neiroendokrinnoi patologiei. Avtoref. dis. ... d-ra med. nauk. M., 1993. [in Russian]

2. Бурдина Л.М. Основные принципы лечения диффузных доброкачественных патологических изменений молочных желез. Маммология. 1996; 4: 9-14. / Burdina L.M. Osnovnye printsipy lecheniia diffuznykh dobrokachestvennykh patologicheskikh izmenenii molochnykh zhelez. Mammologiia. 1996; 4: 9-14. [in Russian]

3. Рожкова Н.И., Бурдина И.И. Клинико-рентгено-патоморфологическая характеристика и лечение диффузных доброкачественных заболеваний молочной железы (мастопатии). М., 2010; c. 30. / Rozhkova N.I., Burdina I.I. Kliniko-rentgeno-patomorfologicheskaia kharakteristika i lechenie diffuznykh dobrokachestvennykh zabolevanii molochnoi zhelezy (mastopatii). M., 2010; s. 30. [in Russian]
4. Рожкова Н.И., Бурдина Л.М., Сметник В.П., Бурдина И.И. Лекарственная патогенетическая коррекция доброкачественных заболеваний молочной железы. Опухоли женской репродуктивной системы. 2008; 2: 48-54. / Rozhkova N.I., Burdina L.M., Smetnik V.P., Burdina I.I. Lekarstvennaya patogeneticheskaya korrektsiya dobrokachestvennykh zabolevaniy molochnoy zhelezy. Opukholi zhenskoy reproduktivnoy sistemy. 2008; 2: 48-54. [in Russian]

5. Рожкова Н.И., Бурдина И.И. и др. Диффузные доброкачественные заболевания молочной железы: диагностика и лечение. Под ред. В.А.Солодкого, Н.И.Рожковой. М.: СИМК, 2012; с. 124. / Rozhkova N.I., Burdina I.I. i dr. Diffuznye dobrokachestvennye zabolevaniya molochnoy zhelezy: diagnostika i lechenie. Pod red. V.A.Solodkogo, N.I.Rozhkovoy.M.: SIMK, 2012; s. 124. [in Russian]

6. Зайдиева Я.З., Балан В.Е. Применение фитоэстрогенов для лечения гипоэстрогенных состояний. РМЖ. 2000; 3: 156. / Zaydieva Ya.Z., Balan V.E. Primenenie fitoestrogenov dlya lecheniya gipoestrogennykh sostoyaniy. RMZh. 2000; 3: 156. [in Russian] 7. Prior JC. Progesterone for symp- tomatic perimenopause treatmentprogesteronepolitics, physiology and potencial for perimenopause. Facts Views Vis Obgyn 2011; 3 (2): 109-20. 8. Samsioe G. Medical and surgical Strategies for treating urogynecological disorders. Int J Ferticl 1996; 41 (2): 139-41.

9. Маммология. Национальное руководство. Под ред. А.Д.Каприна, Н.И.Рожковой. 2-е изд. М., 2016; c. 311-15. / Mammologiya. Natsional'noe rukovodstvo. Pod red. A.D.Kaprina, N.I.Rozhkovoy. 2-e izd. M., 2016; s. 311-15. [in Russian] 10. Седакова И.Е., Александров А.И., Денисенко Я.В., Ищенко Р.В. Опыт лечения при мастопатии у женщин в менопаузе. Онкология. 2008; 10 (4): 429-31. / Sedakova I.E., Aleksandrov A.I., Denisenko Ya.V., Ishchenko R.V. Opyt lecheniya pri mastopatii u zhenshchin v menopauze. Onkologiya. 2008; 10 (4): 429-31. [in Russian] 11. Зайдиева Я.З. Гормонопрофилактика системных нарушений у женщин в перименопаузе. Автореф. дис. ... д-ра мед. наук. М., 1997. / Zaydieva Ya.Z. Gormonoprofilaktika sistemnykh narusheniy u zhenshchin v perimenopauze. Avtoref. dis. ... d-ra med. nauk. M., 1997. [in Russian] 12. Milewicz A, Gejdel E, Sworen H et al. Vitexagnuscastus extract in the treatment of luteal phase defects due to latent hyperprolactinemia. Results of a randomized placebo-controlled double-blind study. Arzneimittelforschung 1993; 43 (7): 752-6.

13. Jarry $H$, Leonardt $S$, Wunke W. Agnuskastusalsdopaminerges. Wirkprinzip in Mastodynon. N Ztsehr Phytother 1991; 12: 77-82.

14. Hoberg E, Sticher O, Orjala JE, Meier B. Diterpene aus Fgni-castifructus und ihre Analytik. Ztsehr Phytother 1999; 149: 3.

15. Sliutz G, Speiser P, Schultz AM. Agnus kastusextraksingibit prolactin secrecion of pituitery cell. Horm Metabol Res 1993; 25: 243-55.

16. Wuttke W, Gorcow C, Jarry H. Dopaminergie compounds in Vitexagnuskastus. In the pub. Phytopharmaka in forschung und klinischerAnwendung. D.Loew, N.Rietbrock (Hrsg). Darmstadt: Steinkopf, 1995; p. 81-91.

17. Сотникова Л.С. и др. Состояние гормональной регуляции при фиброзно-кистозной мастопатии. Мать и дитя. 2011; 1: 342-6. / Sotnikova L.S. i dr. Sostoyanie gormonal'noy regulyatsii prifibrozno-kistoznoy mastopatii. Mat' i ditya. 2011; 1: 342-6. [in Russian] 